\title{
The EU's role in policing the rule of law: reflections on recent Polish experience \\ ROBERT GRZESZCZAK
}

AND

Stephen TerRetT

University of Warsaw, Poland

\begin{abstract}
Although Brexit has understandably been the primary focus of much recent EU-related discussion, it is not the only threat to the EU's long-term stability. The growing impact of populism has already influenced the Brexit referendum result and an anti-liberal resurgence within the EU. Events in Poland have led to criticism of the EU's apparent impotence in counteracting governments determined to implement an antiliberal, national-populist legislative agenda that threatens the rule of law. This article offers a critical analysis of the mechanism contained in Article 7 TEU and the tools created by the European Commission within its New Framework, viewed through the prism of escalating violations of the rule of law in Poland, with particular focus on the destabilisation of the Constitutional Tribunal. It analyses whether such criticisms are justified and, if so, whether a more robust framework for addressing anti-liberal populism is required. We compare the EU's evolution into an organisation that protects individual human rights with its fledgling evolution into an organisation that seeks to police the rule of law. We argue that, in contrast to its successful human rights evolution, the EU's current efforts towards enforcing the rule of law give little cause for optimism.
\end{abstract}

Keywords: EU; rule of law; Article 7; New Framework; European law; democratic backsliding; Polish Constitutional Court

\section{Introduction}

$\mathrm{O}$ 20 December 2017, the European Commission invoked the Article 7(1) procedure of the Treaty on European Union (TEU) for the first time by submitting a Reasoned Proposal for a Decision of the Council on the determination of a clear risk of a serious breach of the rule of law by Poland. ${ }^{1}$ However, at least until the time of writing this analysis, the procedure has not progressed beyond the initial stage and Poland's hearing at the European Council on 26 June 2018. Many factors influenced this process, some of which will be discussed herein. Of course, the confines of this analysis do not allow every interesting or relevant aspect to be taken into account, let alone analysed thoroughly. Consequently, the scope of this analysis is the result of subjective choices made by the authors - for this reason, certain aspects will be examined in greater depth (policing the rule of law in the EU; the inefficacy of Article 7 TEU and the EU's New Framework to Strengthen the Rule of Law (the New Framework); and the debilitation of the Polish

1 Proposal for a Council decision on the determination of a clear risk of a serious breach by the Republic of Poland of the rule of law COM/2017/0835 final - 2017/0360 (NLE). 
Constitutional Court), while some will merely be highlighted (the evolution of the EU's human rights and rule of law competences; and the growing impact of populism), and others will be omitted altogether.

This article argues that recent events in Poland highlight the inadequacy of the EU's existing mechanisms for reacting to perceived rule of law crises, namely Article 7 TEU and the European Commission's New Framework. It compares the EU's evolution into an organisation that protects human rights within its field of jurisdiction with its fledgling evolution into an organisation that also seeks to police the rule of law. It concedes that the evolution of the EU's role in protecting human rights has been lengthy and is subject to an ongoing debate. While its journey towards efficient protection of the rule of law cannot be expected to be less difficult, it is submitted that there is as yet little cause for optimism that it will proceed as far as the human rights protection instrumentarium.

As a case study to our discussion of the EU's current inability to deal effectively with rule of law crises, this article focuses on the Polish government's reform of the Constitutional Tribunal. This is merely one of numerous national reforms which have sparked rule of law concerns, including reforms which have enabled the government to establish de facto control over the Supreme Court (Sad Najwy;ssyy), the state prosecutorial agency, and public television and radio. We concur entirely with Ewa Łętowska, one of Poland's most renowned academics and a former judge of the Constitutional Tribunal, who notes that Poland's current situation cannot be fully understood merely by undertaking an isolated legal analysis of the reforms implemented by the new government. ${ }^{2}$ Nevertheless, we focus almost exclusively here on the government's reform of the Constitutional Tribunal because this was only one of the first significant reforms to be implemented following the elections in 2015, but it was also a sine qua non to ensuring that later reforms were not challenged as unconstitutional.

\section{Comparisons between the evolution of the EU's human rights competences and rule of law competences}

Since the $1950 \mathrm{~s},{ }^{3}$ the institution currently known as the European Union has undergone a radical transformation of its institutional interests and competences regarding human rights and the rule of law. These two latter terms are not entirely synonymous, but they are clearly interrelated.

Any denial of fundamental human rights which derives from a systemic failure to protect principles such as equality before the law, legality of executive power, legal certainty and the independence of the judiciary will also inevitably give rise to a systemic threat to the rule of law. ${ }^{4}$ Yet it must not be forgotten that, during its early years of existence, the European Economic Community (EEC) was, from an organisational perspective, clearly not one which concerned itself with human rights at an individual

2 Ewa Lętowska, 'Zmierzch liberalnego państwa prawa w Polsce' (2017) 1-2 Kwartalnik o Prawach Człowieka 5. The Irish High Court (Case C-216/18, ECLI:EU:C:2018:586) arrived at a similar conclusion, noting at paras 124-1 that: 'certain changes, when viewed in isolation, may not self-evidently appear to violate the rule of law. [However] ... the composition and independence of the Constitutional Tribunal has been compromised and [such reforms] come within a concerted legislative package to politicise the judiciary and to take away its independence'.

3 That is following the creation of the European Coal and Steel Community 1951 and the European Atomic Energy Community (Euratom) and EEC of 1957.

4 See Annexes to the Communication from the Commission to the European Parliament and the Council: A New EU Framework to Strengthen the Rule of Law, Annex I: The Rule of law as a foundational principle of the Union, Brussels, 11 March 2014, COM(2014) 158, final. 
level, and certainly played no role in policing systemic threats to the rule of law per se. ${ }^{5}$ Human rights were effectively considered to be a matter of national law and outside the purview of the EEC itself. Equally, the rule of law was deemed to be a national matter until the Treaty of Amsterdam (1999) introduced this term into the lexicon of EU law.

The current rule of law crises present a comparable problem for the EU by posing a threat to the EU's core values, which, according to Article 2 TEU, include the rule of law and human rights. If the $\mathrm{EU}$ is unable to prevent or redress rule of law crises at a systemic level, this brings into question its ability to ensure the Member States' enforcement of individual human rights. In turn, this undermines the proper functioning of numerous areas of EU law. Thus, an inability to effectively deal with rule of law crises in individual Member States inevitably escalates into a threat to the credibility of European integration on multiple levels.

\subsection{DeVelopment of human RIGHTS PROTECTION By the EU}

From a historical perspective, the EU's growing influence, competences and membership increased the pressure to develop mechanisms for protecting individual human rights. ${ }^{6}$ The initial response of the Court of Justice of the European Union (CJEU) to the human rights predicament' of the 1960s was to develop the doctrine of 'general principles of law' which allowed it to subsume human rights principles and protect them as a matter of European Community law. At first, this occurred via the ad hoc recognition of certain human rights principles derived primarily from the Member States' national constitutions. ${ }^{7}$ Later, it became slightly more structured and coherent by referring more frequently to rights contained in the European Convention on Human Rights (ECHR) to which all the

5 See, for example, Case 1/58 Friedrich Stork and Cie v High Authority of the European Coal and Steel Community [1959] EU:C:1959:4, in which the CJEU effectively declined to exercise jurisdiction in a case concerning human rights issues, since the latter were deemed to fall outside the scope of the EU's founding Treaties as they then existed.

6 It is no coincidence that the CJEU's willingness to enforce human rights as part of EEC law occurred following its 'supremacy' judgment in Case 26/62 Van Gend en Loos v Nederlandse Administratie der Belastingen [1963] EU:C:1963:1 and the German Bundesverfassungsgericht's apparent rejection of this document insofar as EEC law failed to protect human rights that were available to German citizens in the Grundgesetz. The CJEU's change of stance led to a softening of the judicial Cold War which had existed in the EEC since the Van Gend judgment. On the German Bundesverfassungsgericht's approach in the Solange-I judgment (Internationale Handelsgesellschaft von Einfubr- und Vorratsstelle für Getreide und Futtermittel, decision of 29 May 1974, BVerfGE 37, 271 [1974] CMLR 540) and the subsequent acceptance of EU supremacy in the Solange-II judgment (Wünsche Handelsgesellschaft decision of 22 October 1986, BVerfGE 73, 339, case number: 2 BvR 197/83): see Sionaidh Douglas-Scott, 'The European Union and Human Rights after the Treaty of Lisbon' (2011) 11(4) Human Rights Law Review 645-682 and 'A Tale of Two Courts: Luxembourg, Strasbourg and the Growing European Human Rights Acquis’ (2006) 43 Common Market Law Review 629; Christopher McCrudden, 'The Future of the EU Charter of Fundamental Rights' (Jean Monnet Working Paper 10/2001, Jean Monnet Centre 2010) <https://jeanmonnetprogram.org/archive/papers/01/013001.html>.

7 This concept was originally seen in the cases of Case 29/69 Erich Stauder v City of Ulm - Sozialamt [1969] EU:C:1969:57 and Case 11/70 Internationale Handelsgesellschaft mbH, EU:C:1970:114 Nold v Commission, 4/73, EU:C:1974:51, para 13. In the latter of these cases, the CJEU confirmed that human rights principles which were 'common to the Member States' legal systems' would be protected as a matter of EEC law per se. As an example of concrete rights being derived from the Members States' national constitutions, see case C-100/ 88 Oyowe and Troare $v$ Commission [1989] EU:C:1989:638 at para 16, in which the CJEU recognised that: 'the duty of allegiance to the Communities imposed on officials in the Staff Regulations cannot be interpreted in such a way as to conflict with the freedom of expression, a fundamental right which the Court must ensure is respected in Community Law'. See Grainne De Búrca, 'After the EU Charter of Fundamental Rights: The Court of Justice as a Human Rights Adjudicator?' (2013) 2 Maastricht Journal of European and Comparative Law 168-84. 
Member States were signatories. 8 The Treaty of Maastricht (1993) first introduced the protection of human rights as a principle for the EU into the Treaties. These developments form the historical backdrop to two aspects of the EU's evolution into an organisation which protects individual human rights within its field of competence: firstly, the stated desire (and then commitment) for the EU to accede as a member of the ECHR itself; and, secondly, the entry into force of the EU's own Charter of Fundamental Rights. ${ }^{9}$

These essential characteristics of EU law have given rise to a structured network of principles, rules and mutually interdependent legal relations linking the EU and its Member States, and its Member States with each other, which are now engaged, as is recalled in the second paragraph of Article 1 TEU, in a 'process of creating an ever closer union among the peoples of Europe'. This legal structure is based on the fundamental premise that each Member State shares with all the other Member States, and recognises that they share with it, a set of common values on which the EU is founded, as stated in Article 2 TEU. That premise implies and justifies the existence of mutual trust between the Member States that those values will be recognised and, therefore, that the law of the EU that implements them will be respected. ${ }^{10}$

Much has been written about both of these developments, and there is no need to explore them in depth here. Nevertheless, they demonstrate how the EU's evolution into an organisation that effectively protects human rights was, firstly, born from an initial negative fear (regarding Member States' support for the supremacy doctrine) and, secondly, was the result of ongoing Treaty developments and CJEU jurisprudence. ${ }^{11}$

8 The CJEU has stated that the ECHR has special significance, see judgments in ERT, C 260/89, EU:C:1991:254, para 41; Kadi and Al Barakaat International Foundation v Council and Commission, C 402/05 P and C 415/05 P, EU:C:2008:461, para 283.

9 Until its entry into force with the Treaty of Lisbon on 1 December 2009, the Charter's legal status was uncertain and it lacked full legal effect. On 7 December 2000, the European Parliament, the European Council and the European Commission proclaimed the Charter of Fundamental Rights of the EU in Nice (OJ 2000 C 364, 1). The Charter, which at that time was not a legally binding instrument, has the principal aim, as is apparent from the preamble thereto, of reaffirming 'the rights as they result, in particular, from the constitutional traditions and international obligations common to the Member States, the Treaty on European Union, the Community Treaties, the [ECHR], the Social Charters adopted by the Community and by the Council of Europe and the case-law of the [CJEU] and of the [ECtHR]' (see, to that effect, judgment in Parliament v Council, C 540/03, EU:C:2006:429, para 38). For further details, see Sybe de Vries, Ulf Bernitz and Stephen Weatherill (eds), The EU Charter of Fundamental Rights as a Binding Instrument (Hart 2015); Wojciech Sadurski, 'Charter and Enlargement' (2002) 8 European Law Journal 340; Sionaidh Douglas-Scott, 'The Charter of Fundamental Rights as a Constitutional Document' (2004) European Human Rights Law Review 37.

10 Opinion 2/13 of the Court of Justice of the European Union, ECLI:EU:C:2014:2454, paras 166-7; for more, see Bruno de Witte and Sejla Imamović, 'Opinion 2/13 on Accession to the ECHR: Defending the EU Legal Order against a Foreign Human Rights Court' (2015) 40(5) European Law Review 683-705; Steve Peers, 'The CJEU and the EU's Accession to the ECHR: A Clear and Present Danger to Human Rights Protection' (EU Law Analysis, 18 December 2014) <http://eulawanalysis.blogspot.com.es/2014/12/the-cjeu-and-eusaccession-to-echr.html>; Sionaidh Douglas-Scott, 'Opinion 2/13 on EU Accession to the ECHR: A Christmas Bombshell from the European Court of Justice' (UK Constitutional Law Association, 24 December 2014) < https://ukconstitutionallaw.org/2014/12/24/sionaidh-douglas-scott-opinion-213-on-eu-accessionto-the-echr-a-christmas-bombshell-from-the-european-court-of-justice/>; Steve Peers, 'The EU's Accession to the ECHR: The Dream Becomes a Nightmare' (2015) 16(1) German Law Journal 213-22.

11 See generally Armin von Bogdandy, 'The European Union as a Human Rights Organization? Human Rights at the Core of the European Union' (2000) 37 Common Market Law Review 1307; Koen Lenaerts, 'Respect for Fundamental Rights as a Constitutional Principle of the European Union’ (2000) 6 Columbia Journal of European Law, 1, 15; Grainne De Búrca, 'The Road Not Taken: The European Union as a Global Human Rights Actor' (2011) 105(4) American Journal of International Law 649-93; Steve Peers, Tamara Hervey, Jeff Kenner and Angela Ward (eds), The EU Charter of Fundamental Rights. A Commentary (Hart 2014). 


\subsection{THE EU'S MOVE TOWARDS POLICING THE RULE OF LAW}

Historically, the rule of law principle was introduced into the EU legal framework by the ruling in the Les Verts case, ${ }^{12}$ in which the CJEU explicitly recognised it as a founding principle of the EU. It follows from this ruling (in 1986!) that the EU is a community of law, which implies that both the Member States and the institutions are subject to review as regards their compliance with the Treaties, which were also classified as basic constitutional texts in this judgment. Subsequently, the rule of law was codified by the Member States in the Treaty of Amsterdam, and the Treaty of Lisbon confirmed it as a founding principle of the EU, common to all the Member States (Article 2 TEU).

The amendments introduced by the Treaty of Amsterdam enabled the EU to address systemic deficits of its Member States which threaten the rule of law. Two main developments are noteworthy in this context; firstly, the requirement for applicant states to adhere to the rule of law as a precondition for EU membership and, secondly, the possibility to suspend certain rights (albeit not expel a Member State) and to impose sanctions in the event of a serious and persistent breach of the rule of law in a Member State.

The effectiveness of the first development (the accession criteria) has, unsurprisingly, been assessed positively by some ${ }^{13}$ and negatively by others. ${ }^{14}$ Certainly, the accession criteria, and related decisions to acceptance (approval) of the membership of certain candidate countries, have not been devoid of controversy. ${ }^{15}$ However, since these criteria were inapplicable to any countries which were already EU Member States at the time of their adoption, and since they cease to be applicable per se to any candidate country that acquires membership, there is no need to discuss the extent to which the accession criteria are capable of being used to deal with rule of law crises in current EU Member States. Indeed, the essence of contemporary rule of law crises has been described as democratic backsliding, ${ }^{16}$ which aptly epitomises the manner in which Member States are capable of sliding back (with the help of some considerable legislative/executive pushing) from a constitutional system which adequately protected the rule of law into one which ceases to do so. ${ }^{17}$ Nevertheless, the accession criteria remain a significant development in the EU's growing focus on systemic human rights failings, as opposed to merely individual human rights per se.

12 Judgment of the CJEU of 23 April 1986 in case C-294/83 Parti Écologiste Les Verts' v European Parliament, ECLI: EU: C: 1986: 166.

13 Laurent Pech, 'A Union Founded on the Rule of Law: Meaning and Reality of the Rule of Law as a Constitutional Principle of EU Law' (2010) 6 European Constitutional Law Review 367.

14 Ugo Mattei and Laura Nader, Plunder: When the Rule of Law is Illegal (Wiley-Blackwell 2008) 54.

15 Turkey's ongoing attempt to accede to the EU represents perhaps the most obvious example of such controversy. The protracted accession negotiations have been delayed by a half-hearted approach towards compliance with the accession criteria and various worrying anti-democratic developments within Turkey that seem to openly flout those same criteria. This has led to vetoes being announced by individual EU Member States and, more recently, to the European Parliament calling for a complete cessation of negotiations, following a government crackdown against judges, academics and members of the military after a failed attempted coup. For details of the European Parliament's response to such developments, see its Joint Motion for a Resolution dated 23 November 2016 <www.europarl.europa.eu/sides/getDoc.do?pubRef=//EP//TEXT+MOTION+P8-RC-2016-1276+0+DOC+XML+V0//EN>.

16 Nancy Borneo, 'On Democratic Backsliding' (2016) 27 Journal of Democracy 5-19.

17 Wojciech Sadurski, 'How Democracy Dies (in Poland): A Case Study of Anti-Constitutional Populist Backsliding' (Legal Studies Research Paper No 18/01, Sydney Law School 2018) 17-31. 
The second aspect of this shifting focus, and most relevant for the purposes of the present discussion, is the adoption of Article $7 \mathrm{TEU}$, which purportedly enabled the EU to flex its institutional muscles against existing EU Member States in the event of a serious and persistent breach of the rule of law. However, it will be argued that, just as it is difficult for anyone to flex their muscles when their hands are tied behind their back, Article 7 cannot seriously be expected to successfully deal with the political situation currently facing the EU - namely where multiple Member States simultaneously exhibit authoritarian tendencies and make rapid radical changes to their national constitutional systems which threaten the rule of law.

The adoption of, and the support given to, the Commission's New Framework demonstrates a perception, at both EU and Member State levels, that Article 7 by itself is inadequate to remedy simultaneous threats to the rule of law in multiple Member States (and perhaps even in a single Member State). However, reliance on the New Framework to date has done little to convince sceptical observers that it is any more likely to resolve rule of law crises than Article 7 itself. Thus far, Article 7 has not generated any tangible signs of preventing or reversing national constitutional reforms entailing rule of law concerns.

\subsection{THE EU'S PROTECTION OF THE RULE OF LAW TODAY}

An inability to redress threats to the rule of law in certain Member States must be viewed as an inability to ensure full human rights protection throughout the Union as a whole. Nevertheless, the EU at present appears to be ill equipped to act as a forum for effectively protecting the rule of law within its Member States. The EU's reputation as an organisation which both respects and enforces human rights must surely be at risk if it proves unable to adequately respond to national reforms which threaten the rule of law. As noted above, despite the rule of law and individual human rights operating at different legal levels, the existence of an independent judiciary and court system is a sine qua non for the effective enforcement of individual human rights.

National courts are the first bastion for protecting the rule of law. They are bound by the Simmenthal rule, which lies at the heart of the principle of EU law supremacy and provides an example of the 'EU mandate' held by national courts. EU law permits national courts inter alia the right to refuse to apply national law which conflicts with EU law. However, it is not realistically possible for the EU to rely on national courts, in the spirit of the Simmenthal formula, when those courts have been subjugated to the executive power, as is the case in Poland and Hungary. ${ }^{18}$

Despite the abundance of material and analysis pointing towards the conclusion that a serious threat to the rule of law exists which entails a serious threat to the Union's ability to ensure the enforcement of human rights in its Member States, the EU has been unable to practically impact on the situation in Poland, or indeed Hungary. The reasons for this lie in certain inherent weaknesses of the EU law procedures and mechanisms designed to address rule of law crises. These weaknesses are considered next.

18 For more, see generally Editorial Comments, 'Safeguarding EU Values in the Member States: Is Something Finally Happening?’ (2015) 52 Common Market Law Review 619, 625-7; Editorial Comments, 'The Rule of Law in the Union, the Rule of Union Law and the Rule of Law by the Union: Three Interrelated Problems' (2016) 53 Common Market Law Review 597; Editorial Comments, 'About Brexit Negotiations and Enforcement Action against Poland: The EU's Own Song of Ice and Fire' (2017) 54 Common Market Law Review 1309; Guest Editorial, 'A Potential Constitutional Moment for the European Rule of Law: The Importance of Red Lines' (2018) 55 Common Market Law Review 983-96. 


\section{The inefficacy of Article 7 TEU and the New Framework}

Article 7 TEU was intended to function as a corollary of the Copenhagen criteria which must be adhered to by any country wishing to accede to the EU, including stable democratic institutions, guarantees for democracy, the rule of law and human rights, and respect for and protection of minorities. Compliance with these criteria is not only a prerequisite for accession but is also a duty which continues after accession. ${ }^{19}$ Having been warned of the potential for political extremism amidst its own Member States, following the election of Jörg Haider's far-right Austrian government in 2000, the EU was well aware of the risks posed by the accession of 10 formerly communist countries from Central and Eastern Europe. Accordingly, Article 7 TEU (which had originally been introduced to EU law by the Treaty of Amsterdam in 1999) was amended by the Treaty of Nice in 2001 and entered into force in February 2013, shortly before the A10 accessions took place, with the aim being for it to allow the Union to respond to any democratic backsliding which threatened the EU's fundamental values, as expressed in Article 2 TEU. ${ }^{20}$

The situation in Austria in 2000 provided an occasion to launch the Article 7 procedure, but this was not taken. However, action taken by the EU outside the scope of Article 7 (and non-EU actions) proved to be counterproductive and, in fact, intensified nationalistic sentiment in Austria. ${ }^{21}$ This explains why the formation of a similar coalition government in Italy in 2001 was tacitly accepted by the EU. Equally, when it transpired that a number of EU Member States had participated in clearly unlawful political activities such as the CIA-sponsored prisoner transfer programme, no decision was taken to engage Article 7. Diplomatic efforts, combined with the broader cooperation between European governments and the Bush administration, proved to be much more effective in removing the threat than the difficult procedural requirements contained in Article 7.

Article 7 TEU appears to create a powerful weapon to be wielded against any Member State which threatens to depart from the EU's values, as outlined in Article 2 TEU, including the rule of law. It not only allows the European Council to 'determine that there is a clear risk of a serious breach ... of the values referred to in Article 2' and the Council to determine that such a 'serious and persistent breach' exists, but also to 'suspend certain of the rights deriving from the application of the Treaties to the Member State in question, including the voting rights of the representative of the government of that Member State in the Council'. Nevertheless, when faced with simultaneous rule of law crises in multiple Member States, the stringent voting requirements laid down by this Article vastly reduce the likelihood that it will actually be put into practice. Such problems are evident in each of the constituent paragraphs of Article 7, which will be examined next.

19 Robert Grzeszczak, 'The European Transformation of the Legislative, Executive and Judicial Power in Poland' in Ireneusz Paweł Karolewski and Monika Sus (eds), The Transformative Power of Europe (Nomos Verlagsgesellschaft 2015) 19; see Sergio Carrera, Elspeth Guild and Nicholas Hernanz, 'The Triangular Relationship between Fundamental Rights, Democracy and the Rule of Law in the EU, Towards an EU Copenhagen Mechanism' (Centre for European Policy Studies 2013) $<$ www.ceps.eu/system/files/Fundamental\%20Rights\%20DemocracyandRoL.pdf>.

20 Dimitry Kochenov, 'Behind the Copenhagen Facade: The Meaning and Structure of the Copenhagen Political Criterion of Democracy and the Rule of Law' (2004) 8(10) European Integration Online Papers 1-24 <http://www.eiop.or.at/eiop/pdf/2004-010.pdf>; Dimitry Kochenov, EU Enlargement and the Failure of Conditionality: Pre-accession Conditionality in the Fields of Democracy and the Rule of Law (Kluwer Law International 2008); see also Carlos Closa and Dimitry Kochenov (eds), Reinforcing Rule of Law Oversight in the European Union (Cambridge University Press 2016).

21 Wojciech Sadurski, 'Adding Bite to the Bark: The Story of Article 7, EU Enlargement, and Jörg Haider' (2009) 16 Columbia Journal of European Law 385-426. 


\subsection{Problems SuRrounding Article 7: A DOUble-edged SWord}

The first paragraph of Article 7, which may result in the Council determining the existence of a 'clear risk of a serious breach' of the rule of law, requires the Council to act by a majority of four-fifths of its members (not including the recalcitrant Member State). This translates into a requirement that 22 Member States support such a determination. This does not seem to be an unduly arduous burden, given the highly charged nature of the allegations that such a determination entails. However, the absence of any such declaration to date has created a deafening silence that perhaps speaks more than words.

The problems surrounding Article 7(1) are essentially threefold. Firstly, so far, the potential initiators of this procedure have been reluctant to adopt a reasoned proposal. Secondly, there is uncertainty as to whether the Council would agree with such a proposal. Thirdly, even if the Council would approve such a proposal it is unlikely to result in constructive change. These issues will now be examined in turn.

Firstly, the Council's ability to determine the existence of a 'clear risk of a serious breach' of the rule of law is made conditional upon the existence of a 'reasoned proposal by one third of the Member States, by the European Parliament or by the European Commission'. A worrying sign regarding the EU's political will to deploy even the weakest part of Article 7 is that, despite the abundance of evidence which pointed towards the existence of a serious threat to the rule of law in Poland, none of the potential initiators of the Article 7 procedure adopted a reasoned proposal until the Commission did so in December 2017..$^{22}$ This is an incredibly slow reaction time, given that a reasoned proposal may be made by a mere nine Member States or by the European Parliament. As regards Hungary, the European Parliament resolved in May 2017 to begin work on a reasoned proposal. $^{23}$ In November 2017, it also resolved to work on a proposal regarding Poland. ${ }^{24}$ However, no proposal materialised from the Parliament. It is rather difficult to avoid the conclusion that both the Member States and the European Parliament seemed to delegate entirely the task of initiating the Article 7 procedure to the Commission which, in turn, appeared overly determined to avoid Article 7 altogether and work within the auspices of its New Framework, discussed below.

Secondly, even once a reasoned proposal has been made by one of the potential initiators of Article 7(1), there is no guarantee that the Council would confirm the position(s) expressed in the proposal with the required majority. Given the unwillingness of even nine Member States to create a reasoned proposal themselves, it should not be taken for granted that the support of 22 Member States will be forthcoming. Hungary's

22 See Reasoned Proposal in accordance with Article 7(1) of the Treaty on European Union Regarding the Rule of Law in Poland: Proposal for a Council Decision on the Determination of a Clear Risk of a Serious Breach by the Republic of Poland of the Rule of Law, Brussels, 20 December 2017 COM(2017) 835 final, 2017/0360 (APP).

23 See 'Hungary: MEPs to Assess whether There Is a Risk of Seriously Breaching EU Values' (Press Release, European Parliament, 11 October 2017) <www.europarl.europa.eu/news/en/pressroom/20171011IPR85823/hungary-meps-to-assess-whether-there-is-a-risk-of-seriously-breaching-euvalues $>$.

24 See 'Rule of Law and Democracy in Poland at Risk: Parliament Ready for Next Steps' (Press Release, European Parliament, 15 November 2017) <www.europarl.europa.eu/news/en/pressroom/20171110IPR87824/rule-of-law-and-democracy-in-poland-at-risk-parliament-ready-for-next-steps $>$. 
Prime Minister has already declared that Hungary would not support any deployment of Article 7 against Poland ${ }^{25}$ and the same would presumably prove true vice versa, although the Polish government has not issued a comparable official statement. Other Member States might also refrain from supporting Article 7 actions against Poland or Hungary for a variety of reasons relating to their own political agendas. The UK is currently engaged in awkward negotiations with the EU regarding Brexit and future trade relations. Although the 'Brexit deal' itself can be approved by 20 of the 27 remaining EU countries, provided that such countries also represent 65 per cent of the EU population, any future trade deal between the UK and the EU will almost certainly require the unanimous support of all Member States and therefore be vulnerable to a veto by either Hungary or Poland. Accordingly, the UK's concerns for its own future trade relations may trump any concerns it may otherwise have vocalised regarding the rule of law situation in Poland and Hungary. The point here is not to estimate the likely outcome of any vote on Article 7(1) but merely to emphasise that national political concerns may reduce the number of Member States willing to vote in favour of action against those states. A number of recent political events, including the Brexit referendum and the most recent American elections, (should) have taught us to be sceptical about claiming an ability to predict voting results ex ante, and we submit that this may also apply to any vote on Article 7(1).

An additional issue concerning the Council's approval of a reasoned proposal is that it will inevitably further delay any EU reaction to the rule of law crises underway in Hungary ${ }^{26}$ and Poland. The essence of any constitutional capture is that it happens rapidly and, if unchecked, can quickly destabilise existing constitutional mechanisms in a manner that makes it very difficult to restore the original balance. ${ }^{27}$ Nevertheless, aside from the delays in formulating a reasoned proposal, the procedural requirement contained in Article 7(1) for the Council to 'hear the Member State in question' before voting on the proposal will invariably further delay the Council's determination, not least of all because the manner in which such a 'hearing' would occur remains undefined and would perhaps lead to disagreements amongst the Member States. Moreover, the possibility for the Council to 'address recommendations to [the recalcitrant State], acting in accordance with the same procedure' also opens the door to potentially extensive delays in the Council voting on the proposal itself. We do not suggest that no procedural safeguards should exist to protect a Member State accused of violating the values in Article 2, but merely wish to highlight the dichotomy between the delays caused by such procedures and the need to ensure early intervention which prevents or at least limits the extent of any national constitutional capture. One may question whether, in light of the ongoing dialogue which occurs between the EU and the relevant Member State within the scope of the New Framework, the understandable desire to protect the et audi alteram partem principle is not already sufficiently protected and need not be duplicated in the manner envisaged in Article 7(1), which was drafted prior to the New Framework's existence. If this were considered too radical a proposition, at least one should consider

25 See 'Hungary's Orban vows to Defend Poland from EU Sanctions' Financial Times (London 22 July 2017) <www.ft.com/content/b1bd2424-6ed7-11e7-93ff-99f383b09ff9>.

26 Zoltan Szente, 'Challenging the Basic Values: Problems in the Rule of Law in Hungary and the Failure of the EU to Tackle Them' in Andras Jakab and Dimitry Kochenov (eds), The Enforcement of EU Law and Values: Ensuring Member States' Compliance (Oxford University Press 2016) 466.

27 See Laurent Pech and Kim Lane Scheppele, Illiberalism Within: Rule of Law Backsliding in the EU (Cambridge Yearbook of European Legal Studies 2017) 19, 3-47; and Laurent Pech and Kim Lane Scheppele, 'Poland and the European Commission, Part II: Hearing the Siren Song of the Rule of Law' (Verfassungsblog, 6 January 2017 ) <http://verfassungsblog.de/poland-and-the-european-commission-part-ii-hearing-the-siren-song-ofthe-rule-of-law $>$. 
whether the 'hearing' envisaged in Article 7(1) should be organised as expeditiously as possible, given the Member State's ongoing ability to present its viewpoints within the New Framework's procedure.

The third, and perhaps most significant, observation regarding the likely inefficacy of Article 7(1) is that, even if a reasoned proposal is formulated and approved, we consider that it would have little practical effect on a country accused of having created a 'clear risk of a serious breach' of the rule of law, given the specific political situation which exists in such countries. As regards the situation in Hungary and Poland, by the time any serious thought was given to deploying Article 7, the nationalist governments in control of those countries had already built up political support based on radical reforms to their national legal (and/or constitutional) systems. Any backtracking or delays regarding those radical reforms, which lie at the heart of the rule of law crises in those countries, could have catastrophic political consequences for those national governments. Accordingly, any attempts by the EU to broker a political solution, at a time when such reforms were well underway, seems doomed to failure. ${ }^{28}$ Accordingly, the first paragraph of Article 7 appears unhelpful if it will only be deployed against a Member State which has crossed the political Rubicon and burned its diplomatic bridges.

Article 7(2) TEU states that:

The European Council, acting by unanimity on a proposal by one third of the Member States or by the Commission and after obtaining the consent of the European Parliament, may determine the existence of a serious and persistent breach by a Member State of the values referred to in Article 2, after inviting the Member State in question to submit its observations.

The procedural difficulties of this part of Article 7 are so blatant as to require little or no explanation. The unanimity requirement and the inherent unlikeliness of fulfilling this requirement have already been discussed above.

If a determination is unanimously approved under Article 7(2), the Council, acting by a qualified majority, may decide to suspend 'certain of the rights deriving from the application of the Treaties to the Member State in question, including the voting rights of the representative of the government of that Member State in the Council'.

Certain aspects of Article 7(3) are relatively clear, such as the fact that the suspension of a Member State's right to vote in the Council would also result in the simultaneous suspension of its participation at all levels (working groups, Permanent Representatives Committee) which are responsible for making the real arrangements regarding EU law. Other possible sanctions may include the suspension of the right to participate in the election of Commissioners or the suspension from structural funds and assistance programmes within the Common Agricultural Policy, which may prove extremely painful for Poland. ${ }^{29}$ Equally, it is clear that the imposition of sanctions does not release a Member State from its duty to continue fulfilling its obligations under EU law.

28 Laurent Pech and Kim Lane Scheppele refer to a 'dialogue of the deaf' when discussing this. See Laurent Pech and Kim Lane Scheppele, 'Poland and the European Commission, Part I: A Dialogue of the Deaf?' (Verfassungsblog, 3 January 2017) < http://verfassungsblog.de/poland-and-the-european-commission-part-i-adialogue-of-the-deaf >; Robert Grzeszczak and Ireneusz Paweł Karolewski, 'Bialowieza Forest, the Spruce Bark Beetle and the EU Law Controversy in Poland' (Verfassungsblog, 27 November 2017) $<$ http://verfassungsblog.de/bialowieza-forest-the-spruce-bark-beetle-and-the-eu-law-controversy-inpoland $>$.

29 Kim Lane Scheppele, 'Enforcing the Basic Principles of EU Law through Systemic Infringement Procedures', in Closa and Kochenov (n 20) 105-32 . 
However, the full extent and nature of such sanctions is not clear and it is regrettable that an Article concerning the rule of law should leave such an apparently wide scope of discretion to a political body, with no clear boundaries drawn by the legislation itself.

\subsection{The effectiveness of the New Framework}

The inherent problems contained within the various parts of Article 7 led José Manuel Barroso, the then President of the European Commission, to state: 'we need a better developed range of instruments - it is no longer enough to choose between the soft power of political persuasion and the radical solution of Article 7 of the Treaty'. ${ }^{30}$ In a resolution in 2013 the European Parliament called upon the EU institutions to create a new mechanism to ensure that all Member States continued to adhere to the EU's common values and the Copenhagen accession criteria. ${ }^{31}$ As a result, the foreign ministers of four Member States (Germany, the Netherlands, Denmark and Finland) proposed a special mechanism to monitor the protection of the rule of law in EU countries. ${ }^{32}$ In March 2014, the European Commission presented the Communication 'A new EU framework to strengthen the rule of law'. 33

The adoption of the New Framework was not without controversy. An opinion prepared by the Legal Service of the EU Council in May 2014 stated that the New Framework was inconsistent with the principle of conferral contained in Article 5 TEU, according to which the EU only has such competences as have been conferred on it by the Member States. However, this opinion has been widely criticised. ${ }^{34}$

The New Framework procedure consists of three stages. In the first stage, the European Commission assesses whether there is a real systemic threat to the protection of the rule of law in a given country. In this respect, the Commission relies on the analysis of its own materials, the opinions of independent institutions (such as the Venice Commission and the European Union Agency for Fundamental Rights) and information from Member States and other available sources. If the Commission considers that such a threat really exists, it starts a 'structural dialogue' with the country concerned.

30 President of the European Commission State of the Union 2012 Address, Plenary session of the European Parliament/Strasbourg, 12 September 2012 <http://europa.eu/rapid/press-release_SPEECH-12596_en.htm>.

31 European Parliament resolution on the situation of Roma and on freedom of movement in the European Union <www.europarl.europa.eu/sides/getDoc.do?pubRef=-//EP//TEXT+TA+P7-TA-2010$0312+0+\mathrm{DOC}+\mathrm{XML}+\mathrm{V} 0 / / \mathrm{EN}>$.

32 European Parliament, Working Document I on the situation of fundamental rights in the European Union in 2012, LIBE Committee, Rapporteur: Louis Michel, PE514.668, 21 June 2013, 4. On the discussion in the Aeneral Affairs see <www.consilium.europa.eu/uedocs/cms_Data/docs/pressdata/EN/genaff/136915.pdf >. On the conclusions of the Justice and Home Affairs Council, see <www.consilium.europa.eu/uedocs/cms_data/docs/pressdata/en/jha/137404.pdf>.

33 Communication from the Commission to the European Parliament and the Council: A New EU Framework to Strengthen the Rule of Law, $\operatorname{COM}(2014) 158$ of 10 March 2014.

34 Legal Service, Council of the European Union, Opinion on the Commission's proposed Framework on the Rule of Law of 27 May 2014 (10296/14) and its critique: see for example Armin von Bogdandy, Carlino Antpoehler and Michael Ioannidis, 'A New Page in Protecting European Constitutional Values: How to Best Use the New EU Rule of Law Framework vis-a-vis Poland' (Verfassungsblog, 24 January 2016) $<$ https://verfassungsblog.de/a-new-page-in-protecting-european-constitutional-values-how-to-best-use-thenew-eu-rule-of-law-framework-vis-a-vis-poland/>; also Dimitrij Kochenov and Laurent Pech, 'Better Late than Never? On the European Commission's Rule of Law Framework and its First Activation' (2016) 54(5) Journal of Common Market Studies 1062-74. 
At the second stage of the procedure (unless the matter has been clarified earlier), the Commission publishes a 'rule of law recommendation' addressed to the Member State concerned based on the information collected and the government's response. It is difficult to predict what consequences such a recommendation might have on the credibility of a given Member State, in particular on issues that require mutual trust between countries (e.g. an adequate level of protection of rights and freedoms in the event of a European arrest warrant being executed). As part of the third stage of the procedure, the implementation of recommendations is subject to control by the Commission (so-called follow-up) both in terms of how and when they have been carried out (the recommendation will indicate a specific deadline for their completion). Only if none of these actions bring about the desired effect, in the third stage, the Commission may request the Council to launch one of the mechanisms specified in Article 7 TEU.

In general, the soft procedure aims to fill the gaps between the application of the procedures set out in Article 7 TEU and other soft forms of guaranteeing the basic EU principles. Although the rule of law enforcement procedure is legally independent from Article $7 \mathrm{TEU}$, this is called 'preparation for article 7'. The practice of initiating this procedure for the first time in EU history certainly ensures that Poland features heavily in textbooks on EU law. Conclusions from problems encountered by the European Commission and probable ineffectiveness of this procedure will affect its further shape. And reform seems necessary and inevitable. The open question is whether it will take the form of a change to the EU Treaties or be an entirely new document and a new procedure. Everything, so far, speaks for the first option. ${ }^{35}$

It is worth recalling that, even as regards the comparatively successful human rights endeavour, an important leg of this journey remains uncompleted - namely the EU's formal accession to the ECHR. A comparable development regarding rule of law is unlikely for the reasons explained here. Neither of these features is likely to be repeated with any degree of success as regards the current rule of law crises. Any proposed amendments to the founding Treaties, designed to strengthen the EU's capacity to react to rule of law crises, would be extremely unlikely to garner the necessary unanimity amongst the Member States. Accordingly, the evolution of the EU's capacity to deal with rule of law crises is likely to be a lengthier and bumpier ride than the equivalent journey when it acquired human rights competences. The accession has been made legally possible following the Lisbon Treaty's enactment of Article 6(2) TEU to overcome the obstacle created by the CJEU in its Opinion 2/94 on European Community Accession to the ECHR (1996 ECR 1-01759) and following the ratification of Protocol 14 to the ECHR by all Member States of the Council of Europe. Article 17 of Protocol 14 declares that the ECHR is to be amended to provide that the 'European Union may accede to this Convention'. ${ }^{36}$ The inter-institutional

35 See Dimitry Kochenov and Laurent Pech, 'Upholding the Rule of Law in the EU: On the Commission's "PreArticle 7 Procedure" as a Timid Step in the Right Direction' (Working Paper RSCAS 2015/24, European University Institute, Robert Schuman Centre for Advanced Studies 2015) 11.

36 For the CJEU's discussion (and ultimate rejection) of the EU's accession to the ECHR, see in particular Opinion of the Court of 28 March 1996 on Accession by the Community to the European Convention for the Protection of Human Rights and Fundamental Freedoms, and Opinion 2/13 of the Court (Full Court) of 18 December [2014] EU:C:2014:2454, analysed inter alia by Peers, 'The CJEU and the EU's accession to the ECHR: A Clear and Present Danger to Human Rights Protection' (n 10); see Roberto Baratta, 'Accession of the EU to the ECHR: The Rationale for the ECJ's Prior Involvement Mechanism' (2013) 50(5) Common Market Law Review 1305-32; Steve Peers, 'The EU's Accession to the ECHR: The Dream Becomes a Nightmare' (2015) 16 German Law Journal 213; Daniel Halberstam, “'It's the Autonomy, Stupid!' A Modest Defense of Opinion 2/13 on the EU Accession to the ECHR, and the Way Forward' (2015) 16 German Law Journal 105. 
complexities and political vagaries associated with journeys of this kind should not be underestimated.

It was not clear as to whether the provisions of EU law which concern the rule of law are capable of forming the subject matter of references to the CJEU or will be sufficient basis for the successful launch procedure under Article 258 TFEU. Since the judgment in the Celmer case, it is already clear that this material is applicable to proceedings before the CJEU. ${ }^{37}$ Also, the political stakes are far higher when discussing threats to the rule of law than when discussing individual human rights breaches. Furthermore, when implementing and enforcing its human rights regime, the EU has relied heavily on the assistance and support of national courts, either as the source of preliminary references (which allowed the CJEU to develop the EU's human rights mandate) or as the mechanism for enforcing the CJEU's judgments at a national level. Conversely, in situations where the rule of law is threatened, it is highly likely that the national court system forms part of the problem, as opposed to part of the solution. When national courts have been brought under the de facto control of a government whose actions threaten the rule of law, the EU and the CJEU are deprived of an important piece of the jigsaw for developing EU law.

The EU's inability to rely on national courts when policing the rule of law means that it will be compelled to rely almost exclusively upon its own institutions and mechanisms. However, these mechanisms are much weaker than those which apply to individual human rights enforcement. Both Article 7 TEU and the Commission's New Framework contain procedural limitations making them unlikely to successfully resolve rule of law crises, especially if they occur simultaneously in multiple Member States.

\section{Mechanisms to protect the rule of law within the EU 'in action': the debilitation of the Polish Constitutional Court}

Since the Polish parliamentary elections of 2015 were won by the Prawo i Sprawiedliwośc (Law and Justice) party, it has implemented a series of reforms which it claimed were necessary to 'de-communise' the country - namely to remove all aspects of the Soviet system which, in its view, continued to exist despite the fall of communism in 1989. The government has sought to legitimise many of its reforms by comparing them with legal institutions, mechanisms or procedures which function in other European countries and by claiming that such reforms are required in Poland in order to improve the overall efficiency of the justice system.

These reforms should be viewed systemically and holistically to appreciate the full extent to which the justice system has become entwined with executive power. Viewed as a whole, these reforms constitute wide-reaching restrictions on the scope of individual freedom. They lay the groundwork for an increasingly arbitrary, non-transparent executive which is not subject to any effective judicial supervision. ${ }^{38}$ However, as noted above, this article focuses solely on the debilitation of the Constitutional Tribunal as the fundamental reform which represented a sine qua non for implementing subsequent reforms, particularly because the Polish government has implemented de facto changes to the Polish

37 In the Celmer case C-216/18 Minister for Justice and Equality v Artur Celmer, ECLI:EU:C:2018:586, the CJEU was asked by the Irish High Court to address one of the most serious current legal challenges of the EU: the consequences of restrictions imposed upon judicial independence in one Member State for other Member States of the Union.

38 Position of the Helsinki Committee in Poland - February 2018 <www.hfhr.pl/wpcontent/uploads/2018/02/HCiP_statemenet_15022018.pdf>. 
Constitution without possessing the necessary parliamentary majority that would entitle it to enact de jure constitutional amendments. ${ }^{39}$

The fact that the Polish government sought to paralyse the Constitutional Tribunal's functionality almost immediately upon taking office is not coincidental. The clear aim was to establish control over the Tribunal and thereby preclude any successful challenges to subsequent legislation that would de facto implement constitutional reforms on a wide range of areas without formally amending the constitution. The Polish government had no intention of accepting delays to its legislative agenda that the Tribunal might cause by negative judgments and quickly sought to render the Tribunal toothless by adopting two separate Constitutional Tribunal Amendment Acts (on 19 November and 22 December 2015). The latter of these was the most controversial but, for the sake of simplicity, they will be considered together. The essence of the reforms contained in these two amending Acts was twofold.

Firstly, the government focused on personal (or personne) reforms. The early termination of a Tribunal judge's mandate would no longer be decided upon by the Tribunal's General Assembly but by the Sejm (i.e. the lower chamber of Parliament). Disciplinary proceedings, as a precursor to dismissal, would be capable of bring initiated against a Tribunal judge by the President of Poland or the Minister of Justice. The reforms terminated the tenure of the incumbent President and Vice President and introduced a three-year tenure for the Tribunal's presidency, renewable only once. They stipulated that a Tribunal judge's term of office would formally commence at the moment at which their oath was accepted by the Polish President. Finally, the amendments removed certain core provisions which had previously applied to the Tribunal's judiciary, such as those guaranteeing the independence of Tribunal judges, those governing the composition of the Tribunal and those concerning the preclusion on seeking re-election to the Tribunal.

The second aspect of the government's reforms in the amending Act was to focus on certain procedural characteristics of the Tribunal, again with a view to hamstringing its ability to delay the awaiting constitutional onslaught. Accordingly, the amendment Act increased (from 9 to 13) the quorum of judges required in the Tribunal's most important cases and introduced a two-thirds majority requirement for adopting a judgment.

Another debilitating procedural reform was the removal of the Tribunal's autonomy to organise its own workload by prioritising the order in which it heard cases (i.e. preventing the Tribunal from hearing cases in accordance with their importance). The amendments required that the Tribunal should hear cases in a strictly chronological order, according to the date on which they were filed. It also subjected all pending constitutional proceedings to a six-month 'suspensory period', so that no hearing could occur until this time-delay had passed. Even (unrealistically) assuming that the Tribunal had no backlog of cases on the date the new claim was filed, the effect of these reforms was to guarantee that controversial legislation would remain in force for a considerable period of time before it could be reviewed by the Tribunal.

39 Law and Justice received $37.6 \%$ of the votes cast, which entitled it to 235 (i.e. $51 \%$ ) of the 460 seats in the Sejm (the lower chamber of the Polish Parliament) and 61\% of the seats in the Senate (the upper chamber). Although these results were sufficient to enable it to form the first single-party government since the fall of communism, this clearly fell short of the two-thirds majority required by the Polish Constitution for introducing constitutional amendments. As the Venice Commission noted in its Opinion on the Act on the Constitutional Tribunal, adopted by the Venice Commission at its 108th Plenary Session, Opinion 860/2016, CDL-AD(2016)026 (Venice, 14-15 October 2016) para 127: 'the Polish Parliament assumed powers of constitutional revision which it does not have when it acts as the ordinary legislature, without the requisite majority for constitutional amendments'. 
Ironically, the first litmus test of the Tribunal's ability to respond to unconstitutional legislation was the new Constitutional Tribunal Amendment Act itself. Amongst the many parts of this Act which gave cause for significant concern, certain provisions appeared to clearly contradict the unambiguous text of the Polish Constitution. For example, the new requirement for Tribunal judgments to be approved by a two-thirds majority does not sit easily alongside a constitutional provision stating that: 'Judgments of the Constitutional Tribunal shall be made by a majority of votes.' ${ }^{40}$ Despite containing such clearly contra legem provisions, the entry into force of the amendment Act occurred instantly, without the customary 14-day vacatio legis. ${ }^{41}$ This not only prevented the Tribunal from annulling the statute before it entered into force, but it also led to a number of practical problems regarding whether, and how, its legality should be properly assessed.

Considerable disagreement arose regarding whether the constitutionality of the amendment Act should be reviewed in accordance with the new procedure it itself had laid down, or in accordance with the hitherto procedure. This created a catch-22-style paradox. ${ }^{42}$ If the Tribunal applied the new procedure, contained in the very Act whose constitutionality it was reviewing, and concluded that the Act was unconstitutional (as it ultimately did), critics of the Tribunal would claim that this judgment was non-binding, since it was based on unconstitutional statutory rules (i.e. the unlawful Act). Conversely, if the Tribunal applied the hitherto procedure and concluded that the amending Act was unconstitutional, the judgment would be criticised as non-binding as it had not followed the proper (new) procedure.

After the Constitutional Tribunal was turned into an appendage of the ruling party, the next step was to restructure the ordinary courts, the National Council of the Judiciary and the Supreme Court, which was undertaken simultaneously by a law which was initially adopted in 2017 and subject to a number of amendments in 2018. On 29 July 2017 the European Commission launched infringement proceedings against the Polish Law on the Ordinary Courts inter alia as regards the legality of its provisions governing the retirement of judges and their impact on the independence of the judiciary. The European Commission referred this case to the CJEU on 20 December 2017.

Since early 2016, no significant government legislation has been found to be unconstitutional and it appears likely that this will continue to be the case. Professor Ewa Łętowska has aptly referred to the Tribunal's emasculation as a Pyrrhic victory of politics over the law. ${ }^{43}$ Despite large-scale public demonstrations and protests being held, the ultimate victor was the newly elected government. Having rendered toothless the Constitutional Tribunal, the Polish government was able to move on to other significant - and undoubtedly constitutional - reforms, safe in the knowledge that its legislation would not be declared invalid, regardless of its content, reach or impact. Such reforms established political control over the Supreme Court, the common courts and the judiciary as a whole, the prosecutorial authorities, the secret service and intelligence agencies, the police, the national media and the right to organise mass protests. When

40 The Constitution of the Republic of Poland of 2 April, 1997, as published in Dziennik Ustaw (1997) 78, item 483, Article 190(5).

41 The vacatio legis period of a statute may only be shortened in the event of 'an important interest of the state necessitating immediate effectiveness', Article 4 of the Law on the publication of normative acts and some other legal acts, Dziennik Ustaw (2017) item 1523.

42 For a further discussion of this paradox, see Tomasz Gizbert-Studnicki, 'A State of Constitutional Necessity Versus Standard Legal Reasoning’ (Verfassungsblog, 3 June 2017) <https://verfassungsblog.de/a-state-ofconstitutional-necessity-versus-standard-legal-reasoning $>$.

43 Ewa Lętowska and Aneta Wiewiórowska-Domagalska, 'A "Good" Change in the Polish Constitutional Tribunal?' (2016) 1 Osteuropa Recht 79-93. 
reviewing this package of reforms, during the assessment of an application to surrender a person to Poland pursuant to a European Arrest Warrant, the Irish High Court described them as a 'deliberate, calculated and provocative legislative dismantling by Poland of the independence of the judiciary, a key component of the rule of law'. On the basis of the information in the reasoned proposal of the European Commission and of the findings of the Commission for Democracy through Law and taking into account the effects of the recent legislative reforms to the polish system of justice, the referring court has concluded that, as a result of the cumulative impact of the legislative changes that have taken place in Poland since 2015 concerning, in particular, the Constitutional Court, Supreme Court, the National Council for the Judiciary, the organisation of the ordinary courts, the National School of Judiciary and the Public Prosecutor's Office, the rule of law has been breached in that Member State. The referring court bases that conclusion on changes found by it to be particularly significant:

- the changes to the constitutional role of the National Council for the Judiciary in safeguarding independence of the judiciary, in combination with the Polish government's invalid appointments to Constitutional Tribunal and its refusal to publish certain judgments;

- the fact that the Minister for Justice is now the Public Prosecutor and is entitled to play an active role in prosecutions and that he has a disciplinary role in respect of presidents of courts, which has the potential for a chilling effect on those presidents, with consequential impact on the administration of justice;

- the fact that the Supreme Court is affected by compulsory retirement and future appointments and that the new composition of the National Council for the Judiciary will be largely dominated by political appointees;

- and, lastly, the fact that the integrity and effectiveness of the Constitutional Court have been greatly interfered with in that there is no guarantee that laws in Poland will comply with the Polish Constitution, which is sufficient in itself to have effects throughout the criminal justice system. ${ }^{44}$

It is virtually inconceivable that a fully functioning Tribunal would have permitted this package of reforms to enter into force unchallenged. The extent to which the Polish court system has regressed from traditional European values of judicial independence is perhaps best indicated by the refusal to implement an interim injunction imposed by the CJEU on the continuation of tree felling in the Białowieża primeval forest. ${ }^{45}$

The current controversies surrounding the reform of Poland's Supreme Court resemble the conflict over the Constitutional Tribunal in 2015 to 2016 to some extent. However, the Supreme Court took new steps on 2 August 2018, when it referred five questions to the CJEU and requested a preliminary ruling. All five questions relate (more or less directly) to the principles of (1) independence of the courts and (2) the judicial independence under the circumstances of the rule of law crisis in Poland and thus have a potential of becoming a key aspect of the Polish rule of law crisis. ${ }^{46}$

44 Judgment C-216/18 Celmer (n 37) paras 123 and 21.

45 Robert Grzeszczak and Mateusz Muchel, 'Provisional Measures against EU Member States: An Example of the Białowieża Forest' (2018) 2(2) Eastern European Journal of 'Transnational Relations 21-35 $<$ http://hdl.handle.net/11320/6819>.

46 For more see Robert Grzeszczak and Ireneusz Pawel Karolewski, 'The Rule of Law Crisis in Poland: A New Chapter' (Verfassungsblog, 8 August 2018) < https://verfassungsblog.de/the-rule-of-law-crisis-in-poland-a-newchapter $>$. 
There can be no real doubt as to the fact that the recent reforms in Poland represent a considerable threat to the rule of law. This much has been made clear in the various opinions of the Venice Commission. In March 2016, when evaluating the aforementioned amendments to the Constitutional Tribunal, the Venice Commission concluded that they had had 'severe consequences on the proper functioning of the Constitutional Tribunal [which] will make the Tribunal ineffective as a guarantor of the Constitution'. ${ }^{47} \mathrm{~A}$ separate opinion noted that 'numerous other provisions of the adopted Act would considerably delay and obstruct the work of the Tribunal and make its work ineffective, as well as undermine its independence by exercising excessive legislative and executive control over its functioning'. ${ }^{48}$ This meant that the Tribunal 'cannot play its constitutional role as the guardian of democracy, the rule of law and human rights'. ${ }^{49}$ When reviewing the government's extension of secret surveillance powers available to Poland's law enforcement and intelligence agencies, the Venice Commission concluded that 'the procedural safeguards and material conditions set in the Police Act for implementing secret surveillance are still insufficient to prevent its excessive use and unjustified interference with the privacy of individuals' ${ }^{50}$ Likewise, when reviewing other aspects of the government's reform package, the Venice Commission concluded that:

... the merger of the office of the Minister of Justice and that of the Public

Prosecutor General, the increased powers of the Public Prosecutor General visà-vis the prosecution system, the increased powers of the Minister of Justice in respect of the judiciary (Act on the Organisation of Common Courts) and the weak position of checks to these powers (National Council of Public Prosecutors) result in the accumulation of too many powers for one person. This has direct negative consequences for the independence of the prosecutorial system from political sphere, but also for the independence of the judiciary and hence the separation of powers and the rule of law in Poland. 51

Subsequent reforms to the Polish Supreme Court and common courts were described as creating 'a serious risk for the functioning of Polish democracy' and, at least to some degree, 'the proposed system is even worse than its Soviet predecessor' 52 and 'jeopardises the stability of the Polish legal order'. ${ }^{53}$ Accordingly, it is patently clear that the Venice Commission considered the situation in Poland to represent a serious threat to the rule of law.

The negative opinion of Poland's legislative reforms was also shared by the European Commission in a number of Opinions regarding the rule of law in Poland. The Commission has noted that the reforms 'prevented [the Polish Constitutional Tribunal]

47 See Opinion on amendments to the Act of 25 June 2015 on the Constitutional Tribunal of Poland, adopted by the Venice Commission at its 106th Plenary Session, Opinion 833/2015, CDL-AD(2016)001 (Venice, 1112 March 2016) para 88.

48 See Opinion on the Act on the Constitutional Tribunal, adopted by the Venice Commission at its 108th Plenary Session, Opinion 860/2016, para 123.

49 Ibid para 128.

50 See Opinion on the Act of 15 January 2016 amending the Police Act and certain other Acts, adopted by the Venice Commission at its 107th Plenary Session, Opinion 839/2016, CDL-AD(2016)012 (Venice, 10-11 June 2016) para 132.

51 See Opinion on the Act on the Public Prosecutor's office, as amended, adopted by the Venice Commission at its 113th Plenary Session, Opinion 892/2017, CDL-AD(2017)028 (Venice, 8-9 December 2017) para 115.

52 See Opinion on the Draft Act amending the Act on the National Council of the Judiciary; on the Draft Act amending the Act on the Supreme Court, proposed by the President of Poland, and on the Act on the Organisation of Ordinary Courts, adopted by the Commission at its 113th Plenary Session, Opinion 904/2017, CDL-AD(2017)031 (Venice, 8-9 December 2017) paras 43 and 61.

53 Ibid para 63. 
from fully ensuring an effective constitutional review [so that] there will be no effective scrutiny of compliance with fundamental rights of legislative acts. This raises serious concerns in regard of the rule of law'. ${ }^{54}$ As early as July 2016 the European Commission had officially declared that 'there is a situation of a systemic threat to the rule of law in Poland. 55 This clear acknowledgment of the seriousness of the situation in Poland was repeated in other Commission Recommendations made in December 2016, 56 July 201757 and December 2017.58

\section{Conclusion}

The foregoing analysis demonstrates the ineffectiveness of instruments designed to compel respect for and compliance with the EU's core values. Such inefficacy limits the possibility of adequate responses in the event that those values are violated and prevents the effective protection of a vital EU interest - maintaining the integrity of its value.

The EU's transformation, from being an institution which essentially dealt with purely economic matters into one which has developed and implemented its own human rights regime, has been complex and impressive. However, its evolution into an organisation capable of reacting to, and remedying, threats to the rule of law represents a far more complex and difficult transition. This article began by arguing that certain comparisons can be made between the EU's development into an institution which effectively enforces individual human rights and the first tentative steps towards becoming an effective policer of the rule of law. Perhaps history will show the two developments to have ended with an equally satisfying denouement. At present, however, whereas the EU's first tentative steps towards policing the rule of law may bear some superficial similarity to its journey into human rights protection, the differences between these two excursions are more apparent than the similarities.

Firstly, whereas some initial wariness undeniably existed amongst the Member States as the EU began to enforce human rights as an issue of supranational European law, there did not exist the extent of uncertainty or opposition to human rights protection as exists regarding rule of law issues at the heart of a state's constitutional arrangements. In fact, the CJEU's first steps towards human rights protection were taken precisely because certain Member States, notably Germany, had criticised the absence of such protection at a European level.

Secondly, whereas the EU's human rights competences were progressively developed by the CJEU's jurisprudence, no such possibility exists in relation to the New Framework

54 See Commission Opinion of 1 June 2016 regarding the Rule of Law in Poland, Brussels, 1 June 2016 C(2016) 3500 final <http://phavi.umcs.pl/at/attachments/2016/1001/122909-ruleof-law-opinion-poland-1-62016.pdf $>$.

55 See Commission Recommendation (EU) 2016/1374 of 27 July 2016 regarding the rule of law in Poland, Brussels, 27 July 2016 C(2016) 5703 final [2016] OJ L 217/53 <https://eur-lex.europa.eu/legalcontent/EN/TXT/HTML/?uri=CELEX:32016H1374\&from $=\mathrm{EN}>$.

56 See Commission Recommendation (EU) 2017/146 of 21 December 2016 regarding the rule of law in Poland complementary to Recommendation (EU) 2016/1374 [2017] OJ L 22/65 < https://eur-lex.europa.eu/legalcontent/EN/TXT/PDF/?uri=CELEX:32017H0146\&from $=\mathrm{EN}>$.

57 See Commission Recommendation of 26 July 2017 regarding the rule of law in Poland, complementary to Commission Recommendations (EU) 2016/1374 and (EU) 2017/146, C(2017) 5320 final <https://ec.europa.eu/info/strategy/justice-and-fundamental-rights/effective-justice/rule-law/rule-lawframework_en>.

58 See Commission Recommendation of 20 December 2017 regarding the rule of law in Poland complementary to Commission Recommendations (EU) 2016/1374, (EU) 2017/146 and (EU) 2017/1520, C(2017) 9050 final $<$ http://ec.europa.eu/newsroom/just/document.cfm?action=display\&doc_id=49107>. 
or Article 7, since the CJEU is effectively unable to rule on the core aspects of those mechanisms.

Thirdly, as a corollary of the point above, whereas the EU's adoption of the Charter of Fundamental Rights heavily relied upon, and often codified, the CJEU's case law developments, very little scope exists as regards developing the content of the rule of law. It remains unlikely that the Member States would be capable of adopting EU legislation to provide a clearer, European-wide definition of this principle.

The EU's present inability to remedy rule of law crises seems unquestionable. Viktor Orban's dismantling of the Hungarian constitutional system has been ongoing since 2014 . The rule of law in Poland has been progressively undermined since the elections of 2015 . The EU's long-term inability to prevent, revert or even hinder perturbing reforms within its Member States clearly demonstrates the absence of any effective EU law weapons for reacting to such crises. This does not mean that the EU has become ineffective as an organisation for enforcing individual human rights - the rule of law and individual human rights are not entirely synonymous concepts. However, they are clearly interrelated. An important aspect of human rights protection is to prevent the arbitrary use of state power against individuals. When the national courts are brought under the control of the national government, their ability and willingness to protect individuals against such arbitrary state power are clearly undermined. The absence of national judicial independence may, like a cancer, eat away at the checks and balances which are crucial to the healthy functioning of any democracy. With time, the erosion of the rule of law inevitably erodes the protection of individual human rights. Accordingly, for the EU to continue operating effectively at the level of individual human rights, it is crucial that it develops the capacity to prevent rule of law crises at a systemic level. Currently, however, the prognosis does not look promising.

Accordingly, at the time of writing, it seems unlikely that neither Article 7 nor the New Framework will offer any workable solution to rule of law crises that occur in multiple (even if only two) Member States simultaneously. Both mechanisms rely upon an unlikely degree of cooperation on the part of the wayward Member State or, alternatively, upon securing a seemingly unachievable level of consensus amongst the Member States.

The authors accept that no one could have predicted the existence of simultaneous rule of law crises in multiple Member States. Certainly, this does not appear to have been taken into account when drafting Article 7. Bitter experience has taught us that, given the EU's current level of legal integration, it is improperly equipped to police the rule of law per se. An equally depressing conclusion (based on the experiences in Poland and Hungary) is that Member States' internal mechanisms, designed to guarantee the rule of law, can be relatively easily dismantled by a government which is determined to do so. The practical results of the EU's attempts to police the rule of law have fallen far short of the sublime rhetoric surrounding its potential to do so. The participation of other actors, such as the Council of Europe (Venice Commission) and the Organization for Security and Co-operation in Europe, also appear to have had limited practical significance.

The above essentially leaves the EU with three main policy options. Firstly, it could develop a procedure which enables a more effective response to rule of law crises. However, this is extremely unlikely since it would invariably require Treaty amendments that require unanimity and are therefore impractical at the present moment. Secondly, the EU could resign altogether from its journey towards offering effective protection of the rule of law. However, this would be a political, legal and image disaster for the EU itself and would raise questions about its legitimacy and efficacy at a time of already 
unprecedented EU scepticism. Thirdly, the EU could simply choose to wait out the storm until the currently wayward governments are replaced with ones that are less likely to block Treaty amendments needed to render Article 7 workable in practice. No one, including the authors, can be sure which of these approaches will be adopted by the EU. The greatest danger lies in the possibility that, by such time, the constitutional and political arrangements of certain Member States may have been altered and captured to the point that it becomes extremely difficult to implement a reversal. 